\title{
SYMPOSIUM
}

\section{the more parties, the greater policy stability}

josep m. colomer ${ }^{a, b}$

${ }^{a}$ Institute for Economic Analysis (CSIC), Barcelona, Spain

${ }^{b}$ Georgetown University, Washington, DC, USA

E-mail: josep.colomer@gmail.com

doi:10.1057/eps.2011.34; published online 29 July 2011

\section{Abstract}

This article discusses, models and quantifies the relationship between the number of parties in government and the degree of policy change or instability. Single-party governments, such as those formed in the United Kingdom for several decades, tend to produce very high levels of policy changes and reversals, whereas multiparty coalition governments, such as the ones in Switzerland or Israel, tend to produce a high degree of stability and little policy change. This relationship is studied for 295 elections and the subsequent governments in twenty-four countries since the Second World War. According to the study, there is a strong negative correlation between the number of parties in government and the degree of policy change. The fewer parties in government the more changes, and vice versa.

Keywords party system; policy-making; parliamentary regimes

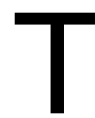

he outcome of the United Kingdom election in 2010 overturned long sustained beliefs about the virtues of Westminster-style governance. At least for a while, the country seemed to be moving to the kind of multiparty coalition politics that is more common in other parliamentary democracies. The new Prime Minister, David Cameron, said that the new Conservative-Liberal coalition government 'marks a clean break from the past and a new start for the country' (media, 25 May 2010). He may have meant a break with not only the previous period of Labour party governments, but with several decades of single-party governments and significant instability of major public policies.

The aim of this article is to analyse, model and quantify the relationship between the number of parties in government and the degree of policy change or instability. The hypothesis to discuss and develop is that the higher the number of parties that participate in government in a political system, the lower the average degree of policy change over time. Single-party governments, such as those that were formed in the United Kingdom from the end of World War II to 2010, 
seem to have produced very high levels of policy changes and reversals. By contrast, coalition governments, such as those formed, for instance, by four parties in Switzerland since 1959, tend to produce a high degree of stability and little policy change. The remarkable difference in the degrees of policy change over time between the two countries mentioned above is represented in Figure 1 . The connection between single-party governments and high levels of policy instability, as well as the alternative advantages for policy continuity provided by coalition governments, such as those, for instance, in Germany, have been acknowledged for quite some time. But there has also been a lot of conjectures that single-party governments can be more committed to responsible policies, while multiparty coalition governments are vulnerable to threats and shifts from minor, sometimes extreme parties, as is frequently argued, for instance, regarding Israel. Much of the political, journalistic and academic discussion about the policy effects of the different types of party government has focused on the experience of a few countries, such as the aforementioned.

In this article, the relationship between the number of parties in government and the degree of policy instability is
'Coalition governments ... tend to produce a high degree of stability and little policy change'.

systematically studied and quantitatively measured for 295 elections and subsequent governments in twenty-four democratic countries since WWII. The main analysis focuses on parliamentary and a few semi-parliamentary regimes, of which eighteen are in Europe, four in Asia-Pacific and one in North America, while a section deals with the United States' regime of separation of powers in a way that could be applied to other countries with comparable institutional formulas.

This work was triggered by two major intellectual contributions. First, the campaign for building theoretically inspired models that can be empirically tested and used for predictions within acceptable margins of error, as promoted and developed by Rein Taagepera.

According to this approach, empirical analyses based on logical grounds should include not only the sign of presumed statistical relationships between political and institutional alternatives (as is usually

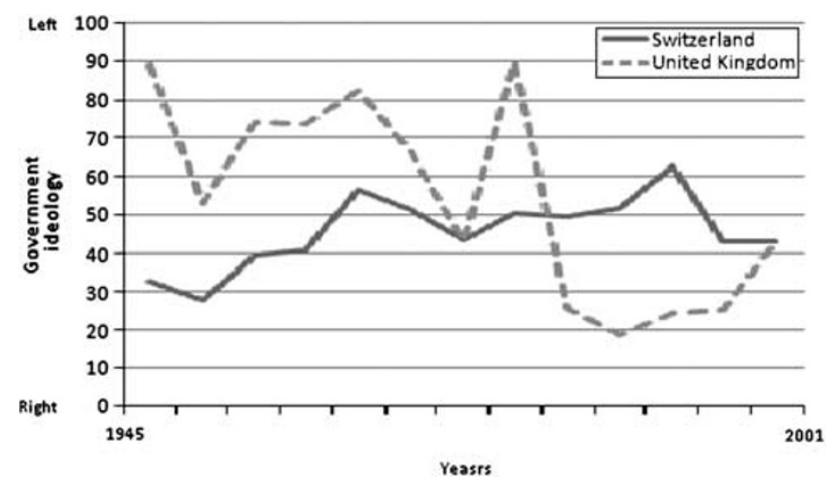

Figure 1 Policy Instability in the United Kingdom and Switzerland.

Source: Author's elaboration with data from Budge et al (2001), Kim and Fording (2002), and Klingemann et al (2006). 
the case in exercises using standard linear regression techniques), but they should be able to appraise gradations of effects and trade-offs among variables in terms of 'how much' one can depend on another and the expected variance of values. This type of 'quantitative logical models' requires some theoretical creativity, but also good quality data permitting the appropriate quantitative measurements (Taagepera, 2008; see also Taagepera et al, 2007).

Thus, the second contribution that made this kind of exercise for the current subject feasible for a large number of cases was the publication of the most extensive data set available on the policies and preferences of parties and governments, as produced by the Party Manifesto project led by Ian Budge. This source provides accurate estimates for every election and government in a few dozen democratic countries during the post-war period, as derived from the programmes, manifestos and platforms of parties and governments themselves. As they are standardised on a scale of 0-100, they permit intra-country, crosscountry and long-term comparisons, as well as associations with more accessible quantitative data sources such as for the numbers of parties (Budge et al, 2001, enlarged and updated by Klingemann et al, 2006; Kim and Fording, 2002, 2010).

The analysis developed in this article confirms the basic relationship: that as the number of parties in government increases, the degree of policy instability decreases. An equation with quantitative values indicates that in comparison with the high levels of policy instability in certain systems with single-party governments, such as the United Kingdom or Greece, a series of two-party coalition governments, such as those in Germany, can reduce policy instability to about half, while three, four or more parties in government, as in Switzerland or Israel,

\section{'... as the number of parties in government increases, the degree of policy instability decreases'.}

to about one third. For the United States, where we find a separation of powers regime, policy instability is almost the lowest in the sample, thus confirming and quantifying the 'gridlock' effects of frequent situations of divided government in a comparative perspective. Hence, the model provides substantive explanatory power of the different degrees of policy instability in different countries with different party and institutional systems. On this basis, the discussion of the actual and expected effects of different types of government on economic, social and other variables can advance on solid ground. As far as the model is empirically robust, it should also supply some predictive capacity and support for advice on the choice of government formulas and of the rules and institutions that tend to produce different types of partisan government.

The next section reviews several previous contributions on the problem. The subsequent section elaborates on the hypothesis. The latter section presents data and operationalisation, on which the fifth section builds the model and its results. The penultimate section briefly deals with the special case of the United States. A few comments conclude.

\section{THE STATE OF THE QUESTION}

Seminal analysis of the policy effects of different types of partisan government emerged, as suggested above, from the study of British politics. As presented, in particular, by Samuel Finer (1975),

josep m. colomer european political science: 112012 
single-party governments, which are typical of parliamentary regimes with plurality rule electoral systems, are the scene of 'adversary politics'. This implies two major consequences. First, singleparty governments, even if they enjoy majority seat support in parliament, are frequently based on only a minority of popular votes and are strongly socially biased. In other words, they are more prone to be captured by minority interest groups and to implement economic and social policies not encompassing broad social preferences. Second, frequent alternations in government of electorally minority and socially biased parties tend to produce policy reversals and instability.

As described by Finer, the British system, in which the plurality winner takes all, 'is one of alternating single-party government' in which a single 'political party controls all decisions in the House of Commons' and 'can legislate in any way it desires'. After every election, 'current policies may be altered very radically indeed', including, for the post-war period under his scrutiny, steel nationalisation, trade union regulations, income taxes, regional, housing, urban, and school policies, fields, among others, in which a 'number of reversals and re-reversals and in some cases, re-re-reversals of policy have occurred'. In contrast, with proportional representation electoral rules and a multiparty system, 'each of the major parties, if it wanted to form a government, would have to cooperate with a party or parties taking a more central stance', which would prevent 'wide swings in policy' (Finer, 1975: 3, 13ff, 31; see also Finer, 1982).

Somehow echoing this early call, a number of studies have addressed the relationship between the different types of partisan government and several policy features, although usually within more complex frameworks including other political and institutional variables. By using statistical correlations and factor analysis, Arend Lijphart set an empirical typology of political regimes based on degrees of concentration of institutional and party powers. The 'majoritarian' or Westminster-type includes single-party governments, while the consensus-type embraces basically parliamentary regimes with proportional representation and multiparty coalition governments. While emphasising the advantages of consensus regimes for maintaining civil peace and other performances, Lijphart remarks, in particular, that alternation of single-party governments 'may entail sharp changes in economic policy that are too frequent and too abrupt' (Lijphart, 1999: 59, following Lijphart, 1984). Digging with these tools, Manfred Schmidt observed large policy effects of the partisan composition of governments in majoritarian regimes, where single-party governments are the rule, while in consensus democracies with multiparty governments and other institutional constraints 'the room of policy manoeuvre by the government is narrowly circumscribed' (Schmidt, 1996).

In a different approach, largely based on 'spatial' measures of policy positions and preferences, John Huber and Bingham Powell found that multiparty parliamentary governments based on proportional representation include the median voter's preference with higher frequency than the typical single-party governments based on majoritarian electoral rules. This may imply that policy positions of multiparty governments can remain relatively more stable around a consensual point. In contrast, singleparty governments are 'essentially unconstrained by other parties in the policymaking process' (Huber and Bingham Powell, 1994; Powell, 2000).

By drawing on some findings in game theory, George Tsebelis produced a non-dichotomic classification of political regimes by counting the number of 'vetoplayers', which in parliamentary regimes 
turns out to be equivalent to the number of parties in government. He consistently emphasises that an increase in the number of 'veto players' increases policy stability, 'impeding significant departures from the status quo', since in order to change policies, more difficult multiparty agreements have to be attained (Tsebelis, 1995, 2002).

Finally, Torsten Persson and Guido Tabellini, focusing on economic policy, also compared the effects of different electoral rules and institutional models, although they did not focus on the intermediate role of political parties. They observed that, on the one hand, in the winner-takes-all model 'only one politician or party holds office and is free to set policy', which predicts 'policy divergence' between successive governments. On the other hand, in the alternative institutional setting (based on proportional representation elections) 'several politicians are in office and bargain over policy', thus producing higher levels of policy convergence (Persson and Tabellini, 2003).

In comparison with these works, the present exercise is different in two ways. On the one hand, it simplifies the analysis by focusing on the policy stability effects of the number of political parties in government. Since the relationships between the number of parties and the electoral system and other institutional variables are well established (see, in particular, Colomer, 2005a; Taagepera, 2007), we can adopt this focus for the sake of parsimony. On the other hand, this article offers precise quantitative measurements and a general equation for the relationship under study, beyond the customary result that it works in the expected direction and is statistically significant. The subsequent effects of policy change on political, economic and other structural variables are only briefly discussed in the final section.

\section{'The room for policy manoeuvre by a single- party government is spacious'.}

\section{HYPOTHESIS}

Two mechanisms can be identified to explain how the number of political parties in government affects the degree of stability or change of public policy. One refers to the allocation of policy issues within government; the other is related to multiparty negotiations on some of these issues.

The first element is related to the number of policy issues that can be the subject of policy debate and public action. In two-party systems, the number of policy issues in electoral campaigns is lower than in multiparty systems, as each party can introduce a limited number of preferred issues in which it can specialise and expect voters' favourable inclination and support (for the relationship between the number of parties and the number of relevant issues, see Taagepera and Grofman, 1985). In a two-party system, an election may be won by a single party on the basis of a small set of issues that turn out to be prominent during the campaign and in voters' information driving their vote. But the election is decisive for all the multiple policy issues that may enter the government's agenda, including those that may have not been taken into serious consideration by many voters at the time of casting their votes. The subsequent single-party government may have a free hand to approve and implement its preferred policies on many issues, even if they have not been salient in the previous debate and campaign. The room for policy manoeuvre by a single-party government is spacious.

josep m. colomer european political science: 112012 
In contrast, in multiparty elections producing coalition cabinets, each party can focus on a different set of issues, globally enlarging the electoral agenda, the corresponding debate and the parties' commitment to well-publicised policies. In the further institutional process, certain issues can be negotiated in a way that the party with more intense preferences on each issue may receive specialised government portfolios and see its preferred policy approved (such as security for Conservatives, finances for free-market Liberals, education for Christian-Democrats, social policy or labour for Social-Democrats, culture for Regionalists, etc.). The allocation of portfolios by specialised distribution and the subsequent policy-making tend to create enduring political support for the decisions on each of these issues.

For other major issues (typically including macroeconomic, interior and foreign affairs policies), multiple political parties may need to negotiate and agree upon decisions about common policy proposals, which are likely not to be completely coincident with any of the preferences of the parties involved, in order to be supported by a parliamentary majority and become law. Intermediate agreements between the parties can settle within relatively moderate, rather 'centrist' sets of policy positions, particularly due to the fact that the higher the number of parties in the system, the closer 'contiguous' parties tend to be located to each other within the limits of available policy 'space' (as illustrated later in this article). Also, as some parties may be pivotal in parliament and be able to form coalitions with different partners, they can introduce elements of policy continuity even if the party composition of successive governments changes (as is especially the case for a number of Liberal, Agrarian, Centrist and Regional parties in different countries in which Social, Democratic or Labour parties, on one hand, and Conservative or Christiandemocratic parties, on the other, may hold the ride).

Both means of policy-making, by specialised distribution of issues and by broad consensus, preclude drastic changes and induce relative policy stability in the mid or long term.

\section{DATA AND OPERATIONALISATION}

Two variables are presented here: the number of parties in government and the degree of policy change, as shown in Table 1. First, the absolute number of parties in government is taken from Jan-Erik Lane et al (1997) and Woldendorp et al (2000). The country-mean values range from one (as in Canada, New Zealand until 1993, Spain and the United Kingdom) to four or more (as in Finland, Israel and Switzerland). The total country-average number of parties in government for twenty-four countries is slightly more than two.

Table 1 also presents the mean effective numbers of parties in government on the basis of calculations for the 295 elections. While their relationship with the degrees of government policy change works in the expected direction and is statistically significant, it does, however, show a weaker association than the absolute number of parties. This may reflect the power of junior partners in government to negotiate not only the distribution of portfolios within government, but also major policy issues requiring multiparty majority support to become government policy, as suggested in the discussion in the previous section. Besides their influence on specific policies, political parties within a coalition government may play a role in checking and balancing collective decision-making on the broad set of government policy issues. 


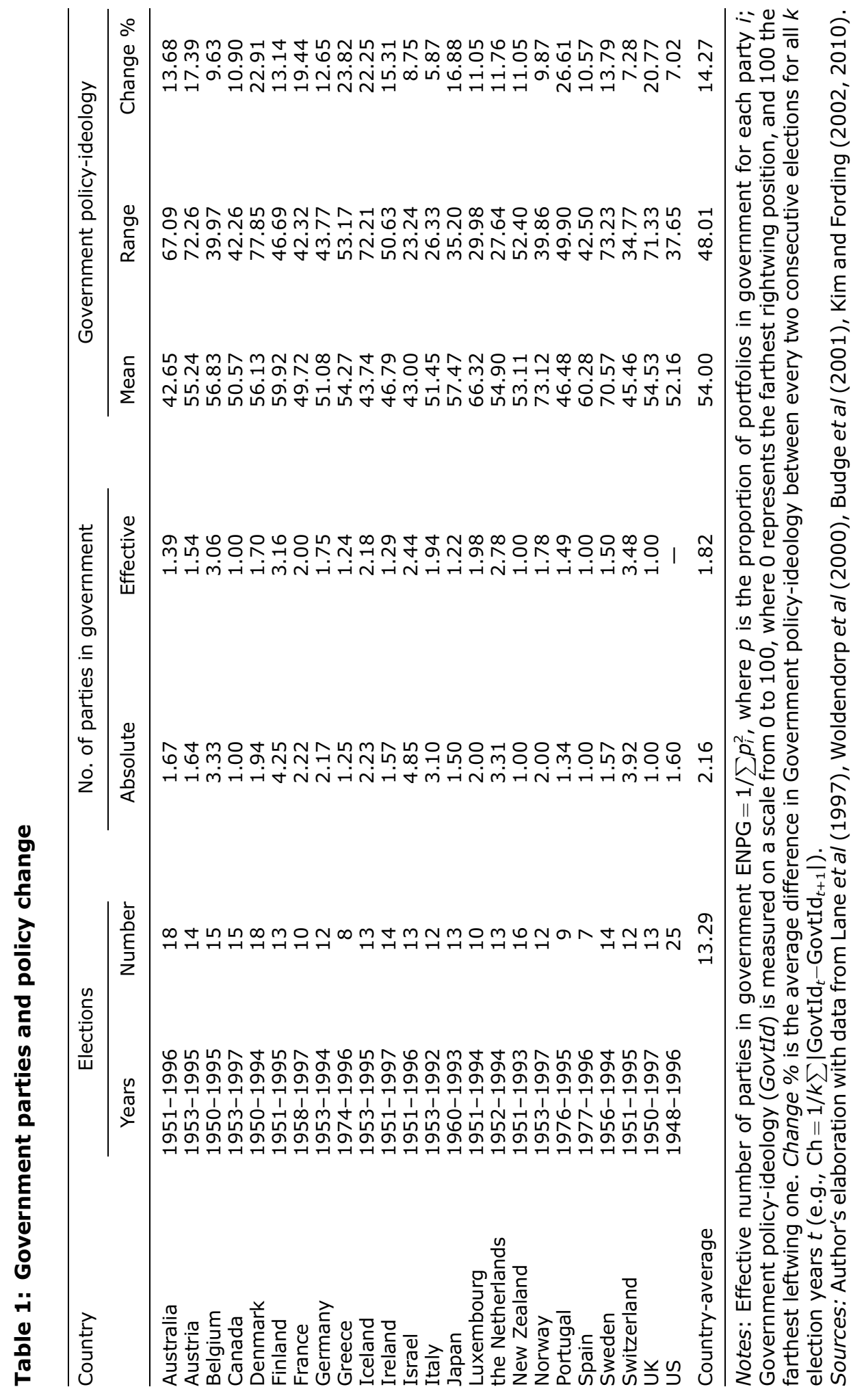


Second, government policy positions have been collected from the abovementioned Party Manifesto Project sources. In this project, the values allocated to each party and partisan government are the result of encompassing collection, reading and codification of party and government programmatic documents for at least fifty-seven policy variables, with several leading indicators based on combinations thereof. Programmatic emphases are interpreted in accordance with 'salience' and 'valence' theory of issues. For instance, left-wing positions are allocated to those devoted to government intervention in the economy, welfare social policy and peaceful internationalism, while right-wing positions are associated with free enterprise, traditional morality and strong defence. Actually, twenty dimensional spaces are created for foreign, regime, socioeconomic (including macroeconomic, labour, agriculture), postmaterialist, moral-religious, ethnic and other policies (See Budge et al, 2001, Tables 3.2, pp. 80-81).

Any measurement of a set of policies may imply some internal variance and, thus, different degrees of policy instability for different issues. But, as a summary, a standardised scale of 0-100 was created on which an extreme right-wing party or government would be scored at 0 , and an extreme leftwing party at 100 . The government 'ideology' is built as a weighted average of government policy positions on all the issues under examination, and given as GovtId in the tables (Kim and Fording, 2002, 2010).

Certainly, party documents and electoral manifestos are not the same as actual policies approved and implemented. Several studies, however, have found high degrees of fulfilment of pledges for action taken by political parties that subsequently entered government, especially for important policy matters (see discussion in Budge et al, 2001: 7-8).

\section{'... a government with majority seat support is able to push its policy proposals through parliament, in addition to controlling the civil service for its implementation'.}

In general, a government with majority seat support is able to push its policy proposals through parliament, in addition to controlling the civil service for its implementation. In fact, it has been observed that extremely high proportions of parliamentary laws are initiated by the government, while about 70-80 per cent of government bills may become law, on average, in parliamentary regimes. Some observable differences would reinforce the hypothesis presented in this article, since in regimes with single-party governments, the government tends to control the parliamentary agenda, while in multiparty regimes the agenda is usually decided by negotiations involving not only the parties in government but also the opposition (see Doring, 1995; Gallagher et al, 2006: 61-66).

None of the 295 governments selected has been located on either of the most extreme positions, 0 and 100 , but the range is very wide: a few right-wing governments score below 20, as in Australia in 1951, Iceland in 1974 (the lowest, at 7.91) and Ireland in 1961, while some left-wing governments go beyond 90, as in Austria in 1970, Denmark in 1971, Norway in 1973 and Sweden in 1960 (the highest, at 97.97). However, the average country-mean government position in twenty-four democratic countries is located at 54 , that is, very near the centre. Polar cases are Australia, Israel and Switzerland on the right side (with mean values below 45) and Norway 
and Sweden on the left side (with mean values higher than 70).

The average range of government positions within a country is 48 percentage points, which can be interpreted as an expectation that the most extreme governments on both sides will hold a mutual distance approximately equal to half the total ideological spectrum (for the governments, countries and periods in the sample). Most interestingly, the range of government positions within a country turns out to be inversely correlated to the number of parties in government. The widest ranges of government positions are found in countries with less than two parties in government, Austria, Denmark, Sweden and the United Kingdom, and the lowest values - that is, the most circumscribed in their choices - for highly multiparty governments, such as those in Israel, Italy (until 1992) and the Netherlands. This observation confirms and even broadens the proposition presented above: that in multiparty systems, the distance between government parties is relatively low, producing coalition policies around intermediate, moderate policy positions (linear correlation with $R^{2}=0.21$ ).

Reliable and complete data on the two above-mentioned variables are available for twenty-four countries for a period of more than fifty years after 1945. On the basis of these data, I have calculated the degree of policy change between each pair of successive elections as the difference between the subsequent governments' policy-ideology scores. The values are percentages of change, which are easily compared across elections and across countries and intuitively understandable as a reference to the maximum possible policy-ideology distance (which would have a value of 100 ).

The mean-country values of policy change may be somewhat underestimated as a consequence of successive appointments of the same party formula after consecutive elections. The capacity for a party government formula to stay in power through several elections should be considered as an element of policy continuity, which would play in favour of the corresponding party system. But, in fact, the proportion of re-elections is almost exactly the same for singleparty governments and for multiparty governments (62 and 60 per cent respectively).

The average policy change between two successive elections in all the countries is about 14 per cent. The highest stability is observed, obviously, for reelected single-party governments with the same prime minister, such as those of the National Party in New Zealand in the 1950s and the Conservatives in Greece in the 1980s, but also for some lasting multiparty coalitions, such as those led by Christian-Democrats in Belgium and in Italy, which eventually became frozen in their policies. On the other hand, the highest levels of change are found in Denmark in 1973 (when a long period of Social Democratic-led governments was momentarily interrupted by an Agrarian-Liberal prime minister) and in the United Kingdom in 1979 (when a very leftist Labour government, scoring more than 90 in 1974, was replaced with a very rightist one, scoring around 26 in 1979 and around 19 in 1983).

\section{THE MODEL}

The two basic variables in our analysis, number of parties in government and degree (or percentage) of policy change, are plotted in Figure 2 for twenty-three country-mean values reflecting their basic institutional relationship (leaving aside, for the moment, the case of the US). Roughly speaking, the data suggest that for single-party governments, we should expect between 20 and 27 per cent

josep m. colomer european political science: 112012 


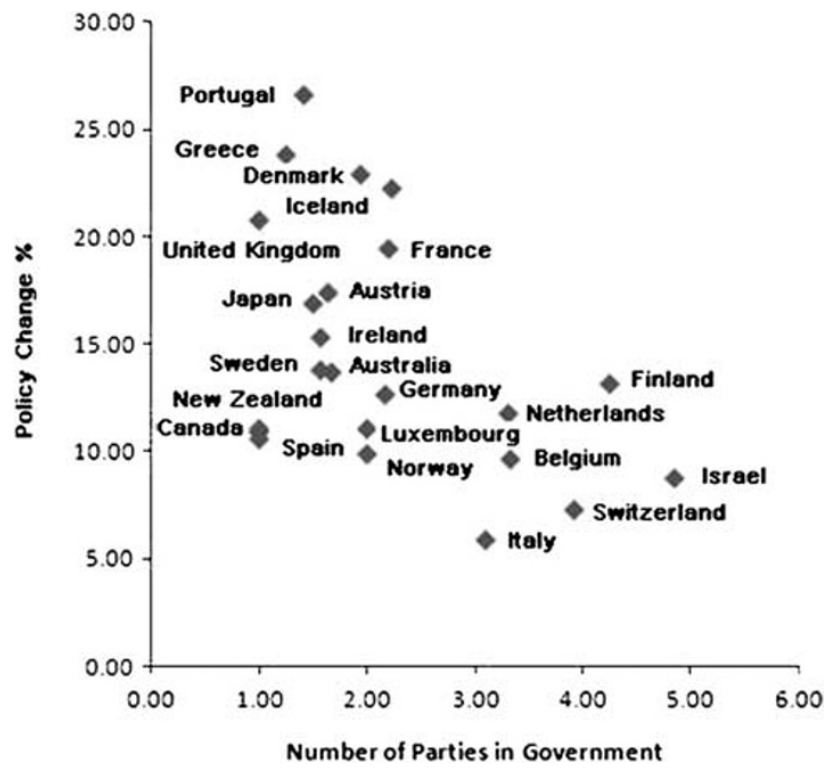

Figure 2 Country-mean values.

Source: Author's elaboration with data as for Figure 1.

of policy change in an average election (which means that it can be much higher when party alternation in the prime ministership occurs, and very low in relatively frequent re-elections). There are a few deviant cases, namely three countries with single-party governments, Canada, New Zealand (until 1993) and Spain, which show low values of policy change. But generally, the degree of policy change seems to be reduced to values of between 10 and 20 per cent for two-party coalition governments and below these figures for three or more parties in government.

The relationship does not appear linear, as an increase in the number of parties in government tends to produce a reduction in policy change, but at a decreasing rate. A division function may, therefore, account properly for this kind of relationship, such as:

$$
y=-\frac{a}{x}
$$

In this case, the independent variable, $x$, is the number of parties in government.
Let us call it NPG. The dependent variable, $y$, is the average degree of policy change. Let us call it $\mathrm{Ch}$ :

$$
\text { Ch }=1 / k \sum \mid \text { GovtId }_{t}-\text { GovtId }_{t+1} \mid
$$

where GovtId is the ideology (or weighted average of policy positions) of each government for all $k$ election years $t$.

Hence, I hypothesise a relationship of the type: $\mathrm{Ch}=\mathrm{a} / \mathrm{NPG}$. In order to find the appropriate value for $a$, I attempt to make an estimate with the arithmetic means of NPG and Ch. This can work, given that all values are positive (no zero score is found for $\mathrm{Ch}$, even if theoretically possible), and the ratio of the largest to the smallest values for both variables is about $5 .^{1}$ The arithmetic mean of NPG is 2.16 , and the arithmetic mean of $\mathrm{Ch}$ is 14.58 , thus making an estimate for $a=$ $2.16 \times 14.58=31.5$. This value can easily be rounded down to about 30 (taking into account, in particular, that the few deviant cases mentioned above have 
lower values than expected). Thus, I propose the following equation:

$$
\mathrm{Ch}=\frac{30 \%}{\mathrm{NPG}}
$$

where $\mathrm{Ch}$ is the mean percentage of government policy change between two successive elections (with the minimum and maximum values 0 and 100 being those found for twenty-four democracies in the second half of the twentieth century), and NPG is the number of parties in government.

The equation is valid for 87 per cent of the countries (20 out of 23 ) within a factor of two, as shown in Figure 3. (It is also valid for 70 per cent of the countries within a factor of 1.5 ; the average deviation between the model prediction and the actual empirical values is $1.48 .^{2}$ ) The equation, the country values and the fit area are plotted in Figure 3. This result, therefore, strongly supports the hypothesis that the higher the number of parties in government, the lower the degree of policy change in successive elections.
As suggested as an outstanding example at the beginning of this article, Switzerland shows a very low level of policy instability (about 7 per cent). This is obviously the result of having had the same four-party coalition in government for more than fifty years, including the Radicals, the Conservative-Christians, the Socialists and the Populists (with an annually rotating chair). But it is worth noting that the lowest level of policy change is found in Italy for the period 1952-1993 (at less than 6 per cent). This experience during the so-called First Republic has been criticised sometimes for its cabinet instability. The present result confirms that frequent rotation of persons in ministerial offices was the other side of tremendous policy stability of a succession of governments led by the Christian-Democrats in coalition with several partners, including the Socialists, the Republicans, the Liberals and the Social Democrats, with an average of more than three parties in government. Very low levels of policy instability are also found for Israel (below 9 per cent), even though the party composition of

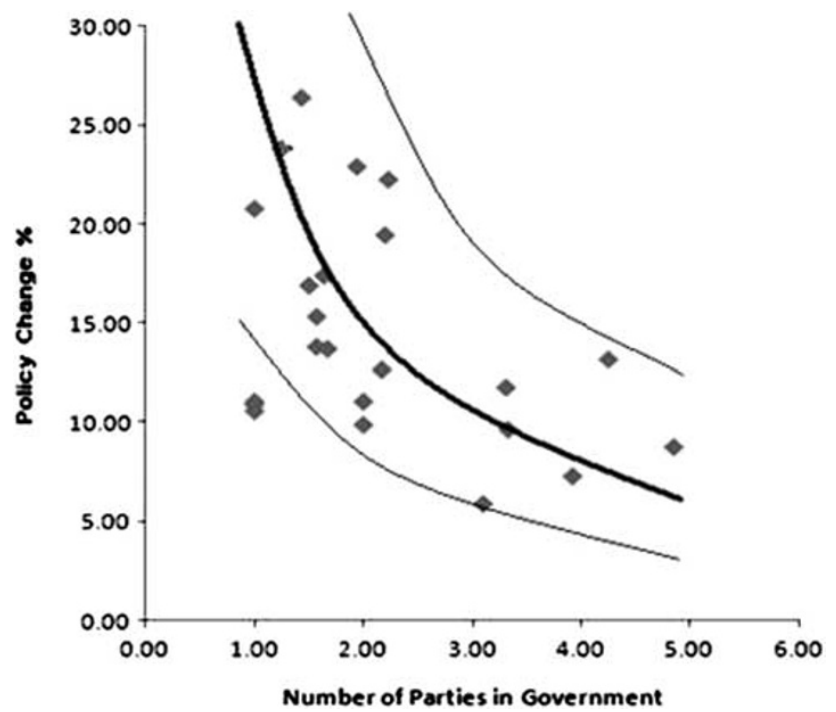

Figure 3 Fit of Equation (2) for 23 democratic countries 1945-1997.

Source: Author's elaboration with data as for Figure 1. 
successive governments changed to some extent, with an average partnership of almost five parties.

Within country comparisons are less accessible with the available data. However, several recent cases clearly show that the direction of the effects of change in institutional rules and the type of party government works in the expected direction. In two cases, a plurality-based electoral system producing single-party governments was changed in 1994 in favour of mixed systems with proportional representation rules that have induced multiparty coalition governments. Accordingly, the degree of policy instability in the following two and three elections for which we have data has decreased: from 16.88 to 12.74 in New Zealand and from 11.05 to 5.17 per cent in Japan (in spite of a previous long period of single-party dominance by the Liberal-Democrats). In Italy, a temporary move in the opposite direction, from pure proportional representation to a mixedmajority electoral system, also produced the expected result of an increase in policy instability in the following three elections from 1994 on (from 6.57 to 30.40 per cent). Further observations should be able to confirm these tendencies and refine values (calculations are performed with the same data sources as for Table 1).

\section{SEPARATION OF POWERS}

A separation of powers' regime, such as is found in the United States, requires different treatment. The Congress and the Presidency must cooperate for legislating and policy-making, as induced by the requirement of majority rule for the former and the veto power of the latter. Analogously to what is observed in parliamentary regimes, if the president's party has a sufficient majority of seats in the assembly, it can legislate and make policy according to its preferences. But in situations in which the president's party does not have a sufficient majority of seats in the assembly, it has to negotiate intermediate policy positions with opposition parties; wide swings in policy can be prevented.

The degree of policy change of the twenty-five president parties from 1948 to 1996 , as given as GovtId in the aforementioned sources, is low, at 7.95. However, two settings can be distinguished. If the president's party has a majority in Congress, or there is 'unified government', I initially assume that the government includes only one party and the president's party policy-ideology prevails. In contrast, for situations of divided government, I count two parties and take the average between the presidential government position, GovtId and the mean congressional policy-ideology, which is given as ParlId in the abovementioned sources. Thus the divided government position is estimated as:

$$
\text { DGovtId }=1 / 2 \mid \text { GovtId }- \text { ParlId } \mid
$$

where values for ideology (or weighted average of policy positions) are given as DGovtId for the divided government situation, as GovtID for the president's party, and as ParlID for the Congress. The mean degree of policy change will be:

$$
\begin{aligned}
\mathrm{Ch}= & 1 / k u \Sigma\left(\text { GovtId }_{t}-\text { GovtId }_{t+1}\right) \\
& +1 / k d \Sigma\left(1 / 2 \mid \text { GovtId }_{t}-\text { ParlId }_{t} \mid\right. \\
& -1 / 2 \mid \text { GovtId }_{t+1}-\text { ParlId }_{t+1} \mid
\end{aligned}
$$

where $\mathrm{Ch}$ is the mean percentage of government policy change between two successive elections for all $k u$ election years with successive unified governments and $k d$ election years with divided governments.

Although this is a straightforward route, it may reflect the different kind of interparty negotiations and agreements that 
can be reached with two different partisan configurations of the institutional setting. (For a more refined model including the president, the veto legislator and the median legislator's positions, see Colomer, 2005b).

The subsequent values for the twentyfive elections in the period 1948-1996 are: $\mathrm{NPG}=1.6$ (which implies a little more time with divided government than with unified government) and an even lower degree of policy change, $\mathrm{Ch}=7.02$ per cent. This somehow confirms the socalled 'gridlock', 'deadlock' or 'paralysis' effect of a regime with separate elections and institutional 'checks and balances'. But, of course, this result is an outlier regarding Equation (2) and the values represented in Figure 3.

An alternative procedure may consider the fact that political parties in the US, given their very high level of personalisation, are barely comparable with those in most parliamentary regimes. Then a higher number of parties could be counted. For periods of unified government, one could also take the average value between the presidential government position and the mean congressional policy-ideology, thus implying that, in order to legislate, the president also has to negotiate with the congressmen of his own party. This assumption may reflect some real features in the policy-making process, although it has been observed that in periods of unified government the president's party discipline increases (King and Ragsdale, 1988). With this assumption, the degree of policy change in the period under consideration would be even lower, at 5.2 per cent, the lowest in all the twenty-four countries examined. This result would approach the values predicted by Equation (2) above. With fit depending on how many parties were counted.

For other countries with comparable regimes of separation of powers and higher party discipline, such as many in
Latin America, the numbers of parties can be counted more precisely and the relationship between different forms of partisan government and the degree of policy instability could be more precisely measured. This may be the subject of further research.

\section{CONCLUSION}

This study has focused on the number of parties in government (NPG) in parliamentary and semi-parliamentary regimes, which is of course a simplification for the complexity of multiple actors that may enter in the policy-making process. This variable, however, has proved to be strongly and inversely correlated with the degree of policy change (Ch) over time, according to the equation: $\mathrm{Ch}=30$ per cent/NPG.

Policy change or instability has been valued differently by different authors depending on whether they praise more clear-cutting electoral promises and executive effectiveness, or broad consensus in decision-making. A number of studies have tried to address the policy consequences of different institutional settings, especially majority or proportional electoral rules and parliamentary or presidential regimes, on variables such as economic growth, budget size, fiscal pressure, public deficit, welfare and social spending, inflation, unemployment, as well as civic peace, electoral participation, political violence, women's representation and others. Most of these exercises have not led to strongly conclusive results. Indeed socioeconomic results may heavily depend on other relevant factors not necessarily correlated with the political system, such as technology availability, country size and external openness. These, in turn, may be correlated to variables such as climate and natural resources, population and human capacities. The political-institutional regime 
should be considered to have only 'remote' consequences on economic and social performance, rather than 'proximate' ones (see a survey in Colomer, 2009).

This article implies a different perspective. By focusing on the intermediate role of political parties in government, it casts light on other understudied aspects of democratic performance. First, the degree of policy stability, as measured here, is compatible with somewhat different ideological orientations of the policies in question, which may be correlated to different socioeconomic and cultural characteristics of different countries and to self-reinforcing political processes in a long-term perspective. But, by itself, institutionally induced high policy stability can reduce people's uncertainty regarding the future and favour investments in capital, education and labour productivity with expected non-immediate returns, as has been remarked in more structurally oriented economic studies (see, for instance, the discussion by Rodrik, 1991).

Perhaps yet more important is the fact that policy stability can be a positive factor for democratic consolidation and people's degree of satisfaction with the political system. If the citizenry can expect only moderate redistributive decisions from government, the policy distance between electoral winners and losers on important issues is low, and if there is broad consensus on some basic values, people will tend to comply with higher probability than in situations prone to sudden drastic changes and recurrent policy swings. Conversely, if there is a single absolute winner concentrating power in government and making policy at will, the losing and excluded actors may be motivated to resist complying and be tempted to break the rules of the game (see, for instance, the discussion in Weingast, 1997; Alexander, 2002; and Colomer, 2010: chapter 8).

This perspective may add an evaluative dimension to the precedent positive analysis. But the findings presented in this article should also be valid for those sympathising with frequent policy changes or stronger capacity of governmental reactions to unexpected shocks. An empirical logical model, such as the one presented here, should help us understand the favourable political and institutional conditions for alternative outcomes and facilitate choice and advice.

\section{Acknowledgements}

This article was elaborated on at the Prince of Asturias' Chair in Georgetown University, in Washington, DC. I acknowledge support from the staff at the BMW Center for German and European Studies and efficient assistance from Drew Howell.

\section{Notes}

1 'For nonlinear relationships... if the ratio of the largest to the smallest reading (both positive) is less than $10 \ldots$ the arithmetic mean can be used as a proxy' for the central tendency (Taagepera, 2008:; see his discussion in chapter 9).

2 Since this is a division function, giving the error ranges as a multiplication can be equivalent to giving the error as a sum \pm of some value for an additive function.

\section{References}

Alexander, G. (2002) The Sources of Democratic Consolidation, Ithaca: Cornell University Press. Budge, I., Klingemann, H.-D., Volkens, A. and Bara, J. (2001) Mapping Policy Preferences: Estimates for Parties, Electors, and Governments, 1945-1998, Oxford: Oxford University Press.

Colomer, J.M. (2005a) 'It's parties that choose electoral systems (or Duverger's laws upside down)', Political Studies 53(1): 1-21. 
Colomer, J.M. (2005b) 'Policy making in divided government: A pivotal-actor model with party discipline', Public Choice 125: 247-269.

Colomer, J.M. (2009) 'Comparative Constitutions', in R.E. Goodin (ed.) The Oxford Handbook of Political Science, Oxford and New York: Oxford University Press, pp. 217-238.

Colomer, J.M. (2010) The Science of Politics. An Introduction, New York and Oxford: Oxford University Press.

Doring, H. (ed.) (1995) Parliaments and Majority Rule in Western Europe, Frankfurt and New York: Campus Verlag/St Martin's Press.

Finer, S.E. (ed.) (1975) Adversary Politics and Electoral Reform, London: Anthony Wigram.

Finer, S.E. (1982) 'Adversary politics and the eighties', Electoral Studies 1: 221-230.

Gallagher, M., Laver, M. and Mair, P. (2006) Representative Government in Modern Europe. Institutions, Parties, and Governments, New York: McGraw-Hill.

Huber, J.D. and Bingham Powell Jr., G. (1994) 'Congruence between citizens and policy makers in two visions of liberal democracy', World Politics 46(3): 291-326.

Kim, H. and Fording, R.C. (2002) 'Government partisanship in western democracies, 1945-1998', European Journal of Political Research 41: 165-184.

Kim, H. and Fording, R.C. (2010) 'The Kim-Fording Measure of Party Ideology', available at http:// hdl.handle.net/1902.1/10542.

King, G. and Ragsdale, L. (1988) The Elusive Executive: Discovering Statistical Patterns in the Presidency, Washington: Congressional Quarterly.

Klingemann, H.-D., Volkens, A., Bara, J. and Budge, I. (2006) Mapping Policy Preferences II: Estimates for Parties, Electors, and Governments in Central and Eastern Europe, European Union and OECD 1990-2003, Oxford: Oxford University Press.

Lane, J.-E., McKay, D. and Newton, K. (1997) Political Data Handbook: OECD Countries, New York and Oxford: Oxford University Press.

Lijphart, A. (1984) Democracies, New Haven: Yale University Press.

Lijphart, A. (1999) Patterns of Democracy, New Haven: Yale University Press.

Persson, T. and Tabellini, G. (2003) The Economic Effects of Constitutions, Cambridge, MA: MIT Press.

Powell, G.B. (2000) Elections as Instruments of Democracy, New Haven, CT: Yale University Press.

Rodrik, D. (1991) 'Policy uncertainty and private investment in developing countries', Journal of Development Economics 36: 229-242.

Schmidt, M.G. (1996) 'When parties matter: A review of the possibilities and limits of partisan influence on public policy', European Journal of Political Research 30(2): 155-183.

Taagepera, R. (2007) Predicting Party Sizes: The Logic of Simple Electoral Systems, Oxford: Oxford University Press.

Taagepera, R. (2008) Making Social Sciences More Scientific: The Need for Predictive Models, New York and Oxford: Oxford University Press.

Taagepera, R., Coleman, S., Colomer, J. and Grofmanm, B. (2007) 'Symposium: Why political science is not scientific enough', European Political Science 6: 111-155.

Taagepera, R. and Grofman, B. (1985) 'Rethinking Duverger's law: predicting the effective number of parties in plurality and PR systems: parties minus issues equals one', European Journal of Political Research 13: 341-352.

Tsebelis, G. (1995) 'Decision making in political systems: Veto players in parliamentarism, multicameralism, and multipartyism', British Journal of Political Science 25: 289-326.

Tsebelis, G. (2002) Veto Players: How Political Institutions Work, Princeton: Princeton University Press and Russell Sage Foundation.

Weingast, B. (1997) 'The political foundations of democracy and the rule of law', American Political Science Review 91(2): 245-263.

Woldendorp, J., Keman, H. and Budge, I. (2000) Party Government in 48 Democracies (1945-1998): Composition, Duration, Personnel, New York: Springer.

\section{About the Author}

Josep M. Colomer is a Research Professor in Political Science at the Institute for Economic Analysis, CSIC, in Barcelona, and Prince of Asturias' Distinguished Visiting Professor at Georgetown University in Washington, DC. He is a member by election of the Academia Europaea and a life member of the American Political Science Association. He is a author of more than thirty books, most recently The Science of Politics (Oxford University Press, 2010). 